\title{
Transgression as Rule: Freebooters in Chinese Poetry
}

\author{
Maghiel van Crevel
}

China's unofficial poetry journals just won't leave me alone. ${ }^{1}$ This pedantic claim sums up my long, evolving relationship with a decidedly niche but significant body of material. I hasten to add that I would not want the journals to leave me alone-and of course it is really the case that I am not leaving them alone. In this spirit, the present essay looks at a recent, remarkable specimen of this extraordinary genre.

But first a brief history. China's unofficial (民間) poetry journals are loosely comparable to Soviet-Russian samizdat publications but also to the "little magazines" associated with early modernism in the West. They emerged after the Cultural Revolution, in the late 1970s. Privately published and circulated through personal networks, they marked the end of the Mao era, when cultural production in China was fully state-controlled. In the 1980s they offered a much-needed alternative to official (官方) publication, in terms of aesthetics, ideological orientation, and the social dynamics of literature and art. At this time, opportunities for official publication remained rare in spite of the "high culture fever" that marked intellectual life, which the journals helped whip up. In the 199os they were instrumental in reviving the poetry scene after the trauma of the 1989 Tiananmen Square massacre (aka June Fourth) and became a

While I am one of the editors of the Sinica Leidensia series, I was not involved in the serieseditorial process for the present volume.

1 In addition to notes taken during regular field trips since 1991, this essay draws on my previous work on the journals at large and on Freebooters. For more detail and references, see Maghiel van Crevel, "From China with Love: Unofficial Poetry Journals in the Leiden University Library," in Jaarboekvoor Nederlandse boekgeschiedenis [Yearbook of Book History in the Netherlands], ed. Saskia van Bergen et al. (Nijmegen: Vantilt \& Nederlandse Boekhistorische Vereniging, 2017), 233-49; and "Walk on the Wild Side: Snapshots of the Chinese Poetry Scene," MCLC Resource Center, 2017 (bit.ly/35qjBzh). Key Chinese-language publications on the journals are Liao Yiwu 廖亦武, ed., Chenlun de shengdian: Zhongguo 20 shiji 70 niandai dixia shige yizhao 沈淪的聖殿：中國 20 世紀 70 年代地下詩歌遺照 [Sunken Temple: Chinese Underground Poetry in the 7os of the 2oth Century-A Portrait of the Deceased] (Urumqi:Xinjiang qingshaonian chubanshe, 1999); Zhang Qinghua 張清華 , ed., Zhongguo dangdai minjian shige dili 中國當代民間詩歌地理, 2 vols. [The Geography of China's Contemporary Unofficial Poetry] (Beijing: Dongfang chubanshe, 2014). 
site of resistance to the commercialization that swept through Chinese life. And in the 2ooos, when the internet had truly arrived in China, they were obviously going to disappear.

Except they didn't. Unofficial print journals continue to be made to this day. And while the poetry scene has changed immeasurably over the forty-plus years we are now into the Reform era, the unofficial journals remain influential, even if officially they don't exist and individual issues normally appear in editions of no more than a couple hundred copies (upward exceptions might have one or two thousand). This is because they are a testing ground for new voices and texts that probe the boundaries of social and political expectations of poetry, an inner-circle enterprise in which the poets themselves take a keen interest.

When I say the journals won't leave me alone (or I them), I mean two things. First, from about 2000 to 2005 , after Chinese poetry had enthusiastically gone online, print-journal-making slowed down and it seemed possible that it might disappear. After all, the Web was a convenient, powerful medium and less tightly censored than print. So I figured the collecting efforts I had undertaken during research trips since the early 199os had come to a natural end. To mark this I wrote a web essay on the subject with an annotated bibliography of the special collection that was established for the journals when I donated my material to the Leiden University library in 2006. ${ }^{2}$ There were then about a hundred titles in the collection, involving several hundred poets, and this was a labor-intensive paper. Perhaps it was motivated by the feeling that the journals embodied a unique, transitional moment between the stifling political control of the past and the infinite online space of the future, which would make it a good moment for bringing them to the attention of readers outside China.

But as noted above, it turned out that the journals were anything but finished. The Web has added a new dimension to Chinese poetry ${ }^{3}$ but it has not killed print. In fact, according to journal collector Shizhongren 世中人 (b. 1972), the foremost authority on the subject, the late 2000 saw a printjournal comeback. This was spurred by two things. One was people's realization of the vulnerability of online publications to political as well as commercial

2 Maghiel van Crevel, "Unofficial Poetry Journals from the People's Republic of China: A Research Note and an Annotated Bibliography," MCLC Resource Center, 2007 (bit. ly/2Sv4ueg), later abridged and updated as "From China with Love."

3 See Michael Day, "Online Avant-Garde Poetry in China Today," in New Perspectives on Contemporary Chinese Poetry, ed. Christopher Lupke (New York: Palgrave Macmillan, 2008), 201-18; Heather Inwood, Verse Going Viral: Chinese New Media Scenes (Seattle: Univ. of Washington Press, 2014); and Michel Hockx, Internet Literature in China (New York: Columbia Univ. Press, 2015), chapter 4. 
forces when several literature websites were shut down and all the data was lost, not to mention day-to-day censorship. Another was re-engagement with print literature once the newness of publishing online had worn off. ${ }^{4}$ In historical perspective, print-journal-making has become a culture in the Reform era, one of many manifestations of the power of poetry as a meme in Chinese cultural tradition. Witness, for instance, the fact that beyond the "avant-garde" (先鋒) poetry with which journal culture is generally associated, it also extends to "subaltern" (底層) writing by members of the precariat of rural-to-urban migrant workers. ${ }^{5}$ The essay and bibliography that were meant to wrap things up are long behind me as I continue to find exciting new material, not just during fieldwork but also through snail mail that lands on my desk in Leiden. So no breaks.

Second, being the "informal publications" (非正式出版物) they are, the journals have hardly been professionally archived in China, but the last few years have seen a surge in interest by major libraries such as those at Nanjing University, Sichuan University, and Fudan University. These institutions are reaching out to private individuals in China who started collecting long ago and they are interested in working with foreign partners such as Leiden University. Hence, over and above the use of the journals in research on other topics, I have found myself returning to them as a project in their own right, together with fellow researchers in China. The Leiden collection now holds over 150 titles and we have begun to digitize the material and make it available online. ${ }^{6}$

The journals are made all across China. They showcase poetics that range from masculine romantic agony to feminist activism and from elitist language games to streetwise indictments of social injustice, in crudely stapled blackand-white photocopies as well as lavishly illustrated bibliophilic productions and everything in between. The present essay looks at a remarkable, recent addition to this heterogeneous body of material: Freebooters (Jianghu 江湖), run by Feng 風 (b. 1968) since 2014, first out of Changzhou and more recently out of Wuxi. No fewer than twenty-one issues have appeared to date, typically of three hundred to five hundred pages in length, sometimes including color plates and always with carefully designed covers that are part artsy, part scifi,

4 Personal communication (fieldwork interview), February 16, 2017.

5 See van Crevel, "Walk" for more on the power of poetry as a meme in Chinese cultural tradition (passim) and the notions of "avant-garde" poetry and "subaltern" writing in China (pars. 82-85 and 98-108). Unofficial publications featuring "subaltern" writing include Dagong shiren 打工詩人 [The Battler Poet], since 2002, recently renamed Dagong shige 打工詩歌 [Battlers Poetry]; and Picun wenxue 皮村文學 [Picun Literature], since 2014.

6 For the digital collection, see bit.ly/2KXDFl 3 . 
and a little surrealist. Further to a brief introduction to Freebooters presented elsewhere, ${ }^{7}$ I focus on this journal because it foregrounds the politics of journal culture. Also, it takes what I have called transgressive discourse on the contemporary Chinese poetry scene to a new level. And finally, there is something ... disorienting? about Freebooters that I would like to tease out.

But first, let's read Feng's best-known poem, “Cold Lyricism” (冷抒情): ${ }^{8}$

On the horizon / grows the sky / In the sky / grow the birds / Under their wings / grow the houses / By the houses / grow the shores / Between the shores / grow the rivers / On the rivers / grow the waves / On the waves / grow the ships / Ships afloat in torrents of time / Ships headed for the horizon / On the horizon / grows the sky / Under the sky / grows the soil / In the soil / grow shadow and light

I give "Cold Lyricism" pride of place as Feng's signature text even though this essay has next to no room for actual poetry citation (hence the sacrilege of using virgules instead of line breaks) and even though "Cold Lyricism" is starkly different from most of Feng's other work-or precisely because it is, thus contributing to the disorienting effect mentioned above. His oeuvre, meaning not just his own poetry but especially his editor's footprint in Freebooters, occasionally feels like it is all over the place and yet it triggers the intuition that it captures something essential about the Chinese poetry scene. Rather than the meditative depiction of the natural world in "Cold Lyricism," much of Feng's other poetry is angry and cynical and rants against repression and corruption in Chinese society - and against those he sees as wannabe poets who sell out to the system (體制), meaning state-sponsored literature. It is with this latter strand in his own writing that his editorial vision for Freebooters resonates most clearly.

The expression from which the journal takes its name, 江湖, romanized as jianghu, is notoriously hard to translate and can be rendered in many different ways depending on the context — which, incidentally, could lead one to speak of hypertranslatability as well as untranslatability. ${ }^{9}$ Jianghu literally means "rivers and lakes" and is an age-old, sentimental term for a world of wanderers and drifters living by their wits and prowess, outside the realm of law and order. Among other things, it signifies rebellion-with-a-grin from the margins of

7 van Crevel, "Walk," pars. 64-68.

8 Feng, 2018. Lingdu yishang de Hanyu 零度以上的漢語 [Chinese above Zero], 9. Unofficial publication. All translations are mine.

9 This passage draws on van Crevel, "Walk," par. 122. 
society against state institutions and elite traditions. In English, for the name of Feng's journal I use the anthropomorphist "freebooters" because journals have agency and personalities, and freebooters bring to mind not just rebellion but also maritime imagery that aligns well with rivers and lakes. But jianghu is also a popular epithet for the (unofficial) poetry scene at large $\mathrm{e}^{10}$ and as such it could be rendered as "the wild side" — which, incidentally, would work for the name of the journal too. At any rate, by calling his journal Jianghu Feng signals that rather than "simply" disseminating texts, he wants to add to the unending tumult on the Chinese contemporary poetry scene: partisan events, polemics, and publishing as a means of staking out territory in the literary field.

\section{Literature and Politics}

The unofficial journal tradition includes a small number of short-lived, truly underground (地下) publications from the late 195os, the 196os, and the early 1970s that were circulated among hand-picked audiences of trusted friends and read in secret. This was underground writing in a fairly literal sense, as distinct from the underground as a metaphor for anti-establishment cultural production, still commonly used today in China as elsewhere. The earliest journals to shed this secrecy and seek outside readers appeared in late 1978, at the turning point between the Mao era and the Reform era. ${ }^{11}$ They include political publications such as Exploration (Tansuo 探索, 1978-1979), a key text of the Beijing Spring movement embodied by the Democracy Wall, but these were quickly and decisively repressed.

The first two journals that put poetry center stage, Enlightenment 啓蒙 (1978-1979) and Today 今天 (1978-1980), were also politically motivated inasmuch as they addressed the horrors of the Cultural Revolution. Enlightenment did so more explosively and less subtly than Today, and Today has had a more enduring legacy in literary history. Beyond addressing specific moments in political history, the act of unofficial publishing retains its generic political potential today in its contestation of cultural production as the prerogative of the state, and later of the state and the market. That said, it is important to note that the journals rarely if ever contain overt political dissent, in contrast to

10 See Tang Qiaoqiao 湯巧巧, Jin ershi nian Zhongguo shige de "shi jianghu” tezheng yanjiu 近二十年中國詩歌的 “詩江湖” 特徵碑究 [A Study of the “Poetry Arena” as a Distinguishing Feature of Chinese Poetry of the Last Twenty Years] (Xinbei: Huamulan chubanshe, 2014).

11 See David S. G. Goodman, Beijing Street Voices: The Poetry and Politics of China's Democracy Movement (London: Marion Boyars, 1981). 
persistent foreign caricatures that make every poet in the People's Republic a freedom fighter. Political dissent is not tolerated by the authorities; and more relevant to this essay, most poets' and editors' primary interest is not in politics but poetry, even if this binary is a simplification.

Freebooters stands out because it suggests allegiance with authors who operate on the borderline between literature and politics - and some of whom count as dissidents who write poetry rather than poets who address politically "sensitive" subject matter, to stay with said binary a little longer. Two such authors died in prison: Lin Zhao 林昭 (1932-1968) and Liu Xiaobo 劉曉波 (1955-2017). Lin was sentenced to twenty years in prison in 1965, for "counterrevolutionary" activities. She had contributed a long poem that mocked Mao to Spark (星火), an underground journal of political resistance whose two issues appeared in Lanzhou in 1960. "Thought reform" left her unrepentant and in 1968 her sentence was converted to the death penalty and she was shot. She was rehabilitated in 1981 and her prison writings were returned to her family, though not in full. In recent years, as her writing has begun to circulate and her story has become more widely known in China and elsewhere, her grave outside Suzhou has been visited by growing numbers of democracy activists and the police now block access around the anniversary of her execution. ${ }^{12}$ Feng has repeatedly hailed Lin as a pioneer of the underground/unofficial scene. On the 2017 anniversary of her death, he posted in the Freebooters WeChat group to say he was stopped from doing a poetry performance at her grave "some years ago" (the photo companion to Freebooters no. 18 has pictures of a crowd that formed on the occasion) and vowed to try again in future.

Liu Xiaobo needs little exposition. An iconoclastic scholar of literature and philosophy and China's best-known political activist, he spent most of the latter half of his life in jail-and hence, when he was given the Nobel Peace Prize in 2010, he was unable to attend the award ceremony, a moment that was captured in the famous empty chair in Oslo. He died of cancer in 2017, still incarcerated. Liu Xiaobo's wife Liu Xia 劉霞 (b. 1961), a poet, painter, and photographer and a dissident by association with her husband, was kept under house arrest for a decade and forced into exile in Germany in 2018. She, too, appears in Freebooters.

12 On Lin Zhao, see Lian Xi, Blood Letters: The Untold Story of Lin Zhao, a Martyr in Mao's China (New York: Basic Books, 2018); Hu Jie 胡傑 (dir.), “Xunzhao Lin Zhao de linghun" 尋找林昭的靈魂 [In Search of Lin Zhao's Soul] (2004, available on YouTube at bit. ly/39WAyEQ or, with English subtitles, in two parts at bit.ly/36E4Kmo and bit.ly/37WIMLr); and Sebastian Veg, Minjian: The Rise of China's Grassroots Intellectuals (New York: Columbia Univ. Press, 2019), 91-96. 
Other dissident-poets or poet-dissidents who feature in the journal include Huang Xiang 黃翔 (b. 1941), Liao Yiwu 廖办武 (b. 1958), Bei Ling 貝嶺 (b. 1959), Meng Lang 孟浪 (1961-2018), Tsering Woeser कें丸ૅ (b. 1966), Shi Tao 師濤 (b. 1968), and Wang Zang 王藏 (b. 1985). Huang was among the earliest voices that protested against the totalitarianism of the Mao years and became the driving force behind Enlightenment and the "Guizhou [Province] undercurrent" in poetry. ${ }^{13}$ Liao, a poet from Sichuan province who rose to prominence in the $198 \mathrm{os}$, is the author of "Slaughter" (屠殺), later renamed "Massacre" (大屠殺), a long poem associated with June Fourth, and of many other politically engaged texts. ${ }^{14}$ Bei Ling and Meng Lang, from Beijing and Shanghai respectively, were among the most visible poetry activists of the 1980s and 199os, often working together and steadily politicizing over the years. All four contributed to various unofficial journals, as poets and as editors; all were detained or imprisoned once or several times for activities on the borderline between literature and politics; and all were eventually forced into exile (Huang in the U.S., Liao in Germany, Bei Ling in the U.S., and Meng first in the U.S. and later in Taiwan and Hong Kong, where he died of cancer). Woeser is a Tibetan poet, journalist, blogger, and activist. Her work has been banned and censored and she has otherwise suffered for her activism, losing her job as a journalist, exiled from Tibet to Beijing, denied a passport, and so on. Shi Tao is a journalist, writer, and poet who was jailed from 2005 to 2013 for his involvement with an overseas Chinese democracy website. Wang Zang's poetry has been politically very outspoken for close to two decades. He has had recurrent brushes with the authorities, leading to a nine-month stint in prison in 2014.

Most if not all of these authors count as sufficiently "sensitive" to make mentioning their name or carrying their work acts of defiance, even if their writing is included among that of less "sensitive" authors and comes without commentary. But they make regular appearances in Freebooters. Some examples: issue no. 2 is dedicated to Liu Xiaobo and Liu Xia; no. 3, to Lin Zhao and Huang Xiang (and Shizhi 食指 [b. 1948], commonly held to have been driven mad by the Cultural Revolution); no. 4, to Liao Yiwu, Bei Ling, and Meng Lang (and Lao Mu 老木 [b. 1963], editor of a trailblazing unofficial poetry anthology in 1985 and exiled to France after June Fourth). As for actual writing by and on these authors, no. 1 lists Liao as one of the recipients of a 2014 "underground" poetry prize-presumably awarded by Freebooters in this simple, performative

13 For scholarship on Enlightenment and the "Guizhou undercurrent," see the references provided in the annotations on this journal in van Crevel, "Unofficial Poetry Journals."

14 See Michael Day, China's Second World of Poetry: The Sichuan Avant-Garde, 1982-1992 (Leiden: DACHS, 2005), 349-56 (bit.ly/39Kcx3U). Day's book is a key work on unofficial poetry. 
speech act—for a poem called "The Old Monk in Prison Ponders Peace" (老和 晌在監獄冥想和平) that clearly refers to the realities of political repression in China $(1 / 237-44) \cdot{ }^{15}$ No. 2 contains a letter from Liao to Bei Ling and Meng Lang on the sorry state of Chinese establishment poetry (2/379-82), and a poem by Wang Zang called "Declaration of War to the China Writers Association" (向中 國作協宣戰) in which the speaker's anger turns to contempt in wicked invective (2/299-300). The table of contents in no. 3 has an item called "Historical Material on Chinese Poetry" (中國詩歌史料); once the reader arrives at the actual text, this turns out to be about the arrest of six Sichuanese poets soon after June Fourth, including Liao $\left(3 / 325^{-28}\right)$. No. 4 has a section called "Frontiers of the Mother Tongue" (母語前沿, a heading that recurs in other issues) containing contributions on and by Liao, with much room for his clash with Chinese establishment authors at the 2015 Berlin Poetry Festival (4/275-90). No. 5 carries work by Woeser (5/147-56); no. 6, an essay by Liao called "For Liu Xiaobo and Liu Xia" (爲劉曉波和劉霞而做) (6/225-29); no. 7, work by Shi Tao (7/348-59), in a category called "Salute" (致敬) that is regularly used in other issues as well. And there is more. For example, the cover of no. 6 visually aligns the numerals 6 and 4 in one of many overt or thinly veiled references to June Fourth; photographs of most of the authors discussed above appear in one or several issues; and they feature in a set of playing cards adorned with poet portraits that is a side product to the journal, with Lin Zhao and Liu Xiaobo as Jokers.

In another sense than that highlighted in the previous section, the politics of journal culture plays out in the relation between the unofficial poetry scene and its official, government-sanctioned and -sponsored counterpart. Starting from the 199os, the boundaries have been blurred and poets cross over all the time. ${ }^{16}$ And while the journals are outside the system, their editors and authors generally do value recognition by the system. Such recognition is manifest in the above-mentioned, recent collecting efforts by university libraries, in official literary histories-Hong Zicheng 洪子誠 and Liu Denghan's 劉登韓 history of contemporary Chinese poetry, for instance, has several chapters on the

\footnotetext{
15 This is how I will cite issue and page numbers in Freebooters, to limit the number of notes.

16 See, for instance, Jacob Edmond, "Dissidence and Accommodation: The Publishing History of Yang Lian from Today to Today," The China Quarterly 185 (2006): 111-27.
} 
1980 s and 199 os that are built around the journals ${ }^{17}$ —and so on. In all, the unofficial journals and the groups and alliances behind them provide yet more evidence for "the high level of organization" of modern Chinese literary practice, ${ }^{18}$ working not so much against official discourse and infrastructure as alongside them and sometimes intertwined with them. On a related point, whereas the journals count as marginal players in the literary field, many are produced by members of a highly educated urban elite who are in a position to wear their "marginality" with pride, and some of whom have close connections to academia.

However, if official and unofficial poetry are not separate worlds, this does not render their distinction obsolete and Freebooters stands out in how it reflects this distinction. Every unofficial-journal-maker is aware that their actions imply relative distance from or proximity to the unofficial and official ends of the spectrum, but Feng is among the most radical voices I have encountered on paper or in person..$^{19}$ His perspective is roughly as follows. In China there are political limits to what one can publish. As such, writing what is politically permissible is a way to get published and to make money. Aside from politically orthodox authors whose work amounts to propaganda with line breaks, most of the poets whose work might be worthwhile have sold out by joining the China Writers Association and/or by participating in activities (co)sponsored by it. Any involvement with the Association makes the poet in question "pseudo-" or "phoney-unofficial" (僞民間); as does the acceptance of sponsorship from other government institutions; as does respect for social, ideological, or political taboos. Among countless poets thus disqualified, a few mostly Beijing-based, well-connected authors who produce worthless, "academic" (學 院) poetry somehow still manage to control the discourse, thus also keeping foreign researchers and translators in the dark about the real deal, meaning a "pure" (純粹) unofficial poetry that is worthy of the name. This shows "academic" poetry's complicity with official culture. By contrast, Feng has called Freebooters "a key battlefront for marginal poets, dissenting poets, niche poets, newborn poets, under-the-radar poets, vanguard poets, independent poets

17 Hong Zicheng 洪子誠 and Liu Denghan 劉登韓, Zhongguo dangdai xinshi shi 中國當代 新詩史 [A History of Contemporary Chinese New Poetry] (Beijing: Beijing daxue chubanshe, 2005). Companion to Modern Chinese Literature, ed. Kirk A. Denton (New York: Columbia Univ. Press, 2016), 47. 
and other pure poets who operate outside the poetry scene [that is controlled by] the Writers Association."20

Crucially, Feng's perspective highlights an authenticity claim made vis-à-vis not just official poetry but also other persuasions within unofficial poetry. ${ }^{21}$ And his perspective is rather absolute, certainly if one considers its feasibility in practice. (Sometimes it is a bit obsessive: during our first interview I felt he might blame the bad weather on the Writers Association as well.) Censorship and self-censorship are an integral part of literary practice in China and internalized as such by all parties involved, and they definitely extend to the unofficial poetry scene. Also, officialdom is everywhere when it comes to event organization, even when this means little more than the seal of approval for activities that are funded and organized by other, unofficial parties. So the dismissal of any and all unofficial-official collaboration would reduce one's impact in terms of event culture, which is a key part of poetic practice in China. Strict adherence to his own rules would, for instance, have kept Feng from coorganizing the 2017 Conference on Schools in Chinese Avant-Garde Poetry, whose list of sponsors was headed by the Zhengzhou branch of the China Literary and Art Federation, followed by poet-businessman (and main sponsor) Lang Mao's 郎毛 cultural communications company, the Tongji University Poetics Research Center, collector Shizhongren's Chinese Poetry Archive ... and something called the Freebooters Art Journal Association.

Needless to say, this is not about checking Feng's or anyone else's practice against their theory, assessing their literary-activist credentials, etc. If Feng breaks his own rules in situations such as the above, this need not diminish the significance of his editorial vision. And of course he knows there are limits to what he can do if he wants to continue making Freebooters, a point he readily concedes in conversation. At the same time, the journal does in fact strike me as compatible with this vision in important ways. Superficially, this is visible in provocations such as Feng's introduction of the Freebooters "underground" poetry prize as a sarcastic send-up of official and "academic-unofficial" (學院民 間) literary prizes (1/245), and Wang Zang's "Declaration of War to the China Writers Association." But Freebooters' realization of Feng's vision also happens at a deeper, structural level.

20 Feng shiren yishujia 風詩人藝術家 public WeChat account, “Jianghu zhong shiren liao Jianghu” 江湖篃詩人聊《江湖》[Freebooting Poets on Freebooters], June 8, 2019 (bit. ly/3aiL6oL).

21 This mechanism has been operational ever since the emergence of the unofficial scene. See Maghiel van Crevel, Chinese Poetry in Times of Mind, Mayhem and Money (Leiden: Brill, 2008), chapter 12. 
First, Freebooters is privately funded (as are most unofficial journals, but it bears reiteration here). Feng was active on the unofficial scene in the late $1980 \mathrm{os}$ and early 199os. Like many other erstwhile poets he then struck out on a business career, and like some other erstwhile poets he came back to poetry in the 20oos, with private money to spend. He has been the journal's main sponsor. When others chip in, this is recognized in their designation as honorary editors of the issue in question. Second, what I know of the better-known authors in the journal is in line with its positioning as against, or emphatically dissociated from, the official poetry scene rather than alongside it or intertwined with it; and I am inclined to think this holds for the lesser-known authors as well, from what I have seen of their poetry and other texts (essays, interviews, memoirs), although I have by no means read the approximately eight thousand pages of Freebooters to date.

Third, when Feng suggests that poetry written by an internationally connected avant-garde posse supported by academic gatekeepers is indistinguishable from propaganda literature, this is a clever rhetorical move- but it is indefensible as soon as we start reading the poetry. As regards the gatekeepers, he seems much less familiar with who is who in Chinese (and foreign) academia than many of my other interlocutors during fieldwork, even if his assertions on the conspiracy of academia and officialdom flow from strategy as much as ignorance. Also, while he is prone to exaggeration, there is certainly some correlation between establishment connections, scholarly attention, and domestic and international fame, and this leads me to a fourth point. It is hard to get a reliable overview of the thousands of people in today's China who count as serious poets at the local, regional, and national levels, not to mention their relative popularity with various audiences (e.g. mainstream, avant-garde, migrant workers, ethnic groups; domestic and foreign); but Freebooters definitely comes across as privileging lesser-known voices.

The earnestness of Freebooters' allegiance with dissident poets does not keep it from celebrating a wide variety of other authors. This shows the tenacity of the "cult of poetry" in contemporary China, ${ }^{22}$ which is reflected in the versatility of the notion of poethood among other things. Thus, while Feng's editorial choices include moments of downright clownery, they also point to an

22 See Michelle Yeh, "The 'Cult of Poetry' in Contemporary China," Journal of Asian Studies 55 (1996): 51-80. 
overarching, romantic fascination with the poet per se as someone whose unique talent and individuality place them outside the social order, at once tragic and glamorous. This fascination is widespread on the poetry scene and it can border on collective narcissism. The "regular" poet's quality of being tragic yet glamorous is different from that of the intellectual who speaks out on political issues and happens to write poetry; but it is also alignable with it. Poethood pulls things together.

As such, Freebooters can accommodate its gestures of respect toward political dissidents side by side with sections on "fallen women" poets (= female sex worker poets), "comrade" poets (= homosexual poets), ${ }^{23}$ Christian poets, singer-poets, rock-n-roll poets, "punk-folksong" poets, dancer-poets, female painter-poets, male painter-poets, photographer-poets, poets who are in wedlock with one another (dissidents Liu Xiaobo and Liu Xia tick this box as well), poets who passed away before their time (often by suicide, a huge topos on the Chinese poetry scene that illustrates the quality of being tragic yet glamorous in macabre fashion), poets with monosyllabic names, and so on.

The monosyllabic names include Bridge (橋), Knife (刀), Gone (離), Meat (肉), Up (豎), Don't (sic, 勿), Flat (橫), and Wind (風 = Feng himself, who claims he was the first poet to pick a single-character pseudonym) (3/1-30). They present a typical example of how playfulness and provocation can combine seamlessly with the Serious Business that poetry ultimately is for these authors. On the one hand, they are as obviously pseudonymous and, in some cases, playful or provocative in Chinese as in English (I have taken only minor translational liberties). But on the other hand, much of these poets' work is in fact quite ... grim, which is what I might settle on if I had but a single English syllable to characterize the poetry in Freebooters across the board. "Fisherman" (漁夫, 3/23), for instance, by the poet called Don't (b. 1969), is a somber, modestly philosophical text:

Every night at sea I catch a few fish / and early in the morning I take them to market / Selling them is my ultimate goal // I have a foul smell about me, I am not liked by others / The sea wind makes me rough and badtempered, I often have evil intent / When my fish are sold out, I feel no gratitude toward the buyers // When I cast my net, the ocean is also a net

23 A spectacular discursive appropriation, "comrade" (同志) has not been stable over time in its connotations. It can encompass broader notions of LGBT+ or queerness, but in mainland China it now mostly refers to gay men and lesbian women (女同志 “female comrade"). 
/ When I've sold all the fish, I am also a fish / Every day, morning and evening, with life selling me this way and that

To be sure, for organizing his tables of contents Feng also avails himself of conventional literary-historical and critical categories such as the poet's birth decade (a favorite category in Chinese literary discourse, with those [born] "after 1970 " and "after 1980" currently getting a lot of air time), their geographical provenance, the schools and trends with which they are affiliated, and their gender. And sometimes he lists them in the order of their names in alphabetic transcription, under an overarching theme such as "after 1970," with the names themselves not actually alphabetized but the list of names punctuated by uppercase roman letters. He also invokes names and titles from imperial Chinahistorical periods, dynasties, literary texts, imperial examination rankings - as section headings, with (to this reader) little semantic value beyond amorphous anchorage in a native tradition. But the more particular and somewhat theatrical categories listed above and their conceptual range add to the sense that Freebooters is special.

\section{$4 \quad$ Transgression as Rule}

The title of this essay and the present section refers to transgression as an organizing principle of Freebooters that is visible from several angles. Its allegiance with political dissidents is but one of these, and not necessarily the most important if what we are after is what this journal means and does in the broader context of unofficial journal culture.

First of all, Freebooters epitomizes what I have called a transgressive discourse in and on contemporary Chinese poetry that is marked by strategic, sometimes theatrical rudeness and other discursive "misbehavior," often with gender-stereotyping overtones and sometimes with machismo and misogyny on full display. This originated in mid-1980s Sichuan, rapidly expanded in the 1990s, and has been taken further in the new century by journals such as The Lower Body (下牛身), The Low Poetry Movement (低詩歌運動), The Trash Movement (垃圾運動), Rubber (橡皮), Loose (頽䓪), and Freebooters. ${ }^{24}$ It involves the flaunting of what conventionally counts as offensive subject matter (defecation, indecorous sexuality, cruelty, cynicism, etc.) and vicious attacks on

24 The locus classicus is the journal Manghan 莽漢 (Macho Men, 1984); see Day, China's Second World, chapter 4. This passage further draws on van Crevel, "Walk," pars. 122-26. 
poets of other persuasion-but also self-mockery. Notably, especially in the last two decades it has also operated as a vehicle for social concern.

Also, Freebooters takes transgression to another level in its regular efforts to survey and inventory the poetry scene. This is a popular pastime among poetry buffs, and Freebooters partakes in a tradition of the journals producing their own, unofficial literary history. This can take the form of annual poetry news round-ups as well as historical, annotated inventories of the journals, reminiscences by key players, and so on. Independence (獨立, since 1998), run by Faxing 發星 (b. 1966) out of Puge in the mountains of southern Sichuan and one of few journals that are not city-based, is a shining example. But while partisanship is not something that is held against journal editors-Faxing gives a lot of space to Sichuan, and why make a journal if you cannot be partisan?Feng is extreme in his transgressions against what we might call the unofficial canon or a shared vision of its history. See, for instance, his contemptuous disparagement of Today $(18 / 24 ; 21 / 13-17$ ), widely considered the fountainhead of the unofficial poetry tradition, even by younger generations who rebelled against it. Or his deeply unbalanced literary-historical overviews of unofficial poetry, in a brief "memorandum" in an early issue (4/451-6o) and more extensively in no. 18, a special issue on the subject, in a manner that is not just selective but positively distorting.

Furthermore, while Freebooters shares with other journals the mobilization of transgressive discourse not just to shock but also to voice social concern, in this journal such concern also takes shape in the many literary-historical and critical categories in which Feng presents his authors and texts of choice; he is right up there with the most fanatical among Chinese poetry's many avid labelers of associations, societies, schools, trends, and so on. Mu Cao's 墓草 (b. 1974) poetry may serve as an example. While sex and sexuality at large and LGBTQ+ subject matter are "sensitive" areas for literature and art in China, Feng is one of few people who have published poetry by $\mathrm{Mu}$ Cao that contains graphic depictions of gay sex, often embedded in social critique. And he categorizes this poetry as "China's Comrade Poets," which is the label under which it appears in the table of contents, published online and hence subject to surveillance (5/121-38); never mind that the category only holds a single author. In the same way, Woeser's poetry appears in the category of "Tibetan Poets" (5/147156); Su Xiaohe's 蘇小和 (b. 1968) poetry, in the category of "China's Christian Poets" (6/107-122); Duoduola's 朵朵拉 poetry, with clear references to sex work, in the category of "China's Fallen Women Poets" (6/55-68); and so on.

Duoduola is something of a mystery and I have been unable to establish when she was born (or, for that matter, whether she is still alive). Poet and 
unofficial publisher Fang Xianhai 方閒海 (b. 1971) recalls that in the late 20oos, Duoduola's poetry was around on the Web, she was considered very talented, she was associated with the style of The Lower Body, and one of various stories circulating about her said she was a sex worker from the countryside; but nobody had ever met her. Based on his correspondence with Duoduola, Fang concludes (without elaborating) that the only thing he knows for sure is that she is in fact a woman. He adds that at the time of writing (2017), she had long “disappeared."25 Duoduola's "Sex and a Record of Events" (性與紀實, 6/64) brings honesty, irony, and sadness together:

This is me, lower than city life / very very tall / standing at the turnoff to the village / making all kinds of seductive movements / trying to lure some pedestrian / to temporarily / abandon wife and child and parents / and linger on my highly expensive bed // What I need at that moment / is just the night / In the morning / I'll be standing there again / watching those who live forever under the horizon / on my lower body / exhausted, smiling, falling asleep

Transgression against social and political norms is also what ties together various social groups for which Freebooters can be seen to advocate, whether or not it does so by explicitly labeling them in the table of contents - and whether or not the poets thus invited to speak do so from personal experience or by assuming a persona. ${ }^{26}$ Several of these groups are vulnerable and suffer discrimination and exclusion, and there is a connection here with my general observation that the journal privileges lesser-known voices. In addition to dissidents, sex workers, homosexuals, and Christians, two other such groups are prisoners and the aforesaid "subaltern" poets. "Subaltern" writing features in one of Feng's "Salute" sections, this one dedicated to the "Beijing Drifter Poets" (北漂詩人, 5/157-62), again featuring a single author, named He Sanpo 何三坡 (b. 1964); "Beijing drifters" is a colloquial expression for rural-to-urban migrant workers in the capital. Incidentally, the famous poet-tramp (流浪詩 人) Zeng Dekuang 曾德曠 (b. 1968) is described as a proto-subaltern poet in

25 Fang's recollections appear on poet Yuan Wei's 袁瑋 (b. 1985) Sohu blog (Fang and Yuan are life partners), bit.ly/35Doorc.

26 Depending on what one wants to know, the latter point is of course of interest in other contexts and will generate discussion on issues of ownership, authenticity, identification, appropriation etc.: Who has the right to speak, to whom, about whom, on whose behalf, to whose exclusion? But it lies outside the scope of the present discussion. I have not tried to establish if Duoduola was or is a sex worker, if Li Bujia spent time in prison (see below), and so on. 
the pages of Freebooters (1/325) - though one could argue that unlike your average migrant worker, Zeng and his fellow poet-tramps relish their exclusion and are outsiders by choice, by épater le bourgeois and turning transgression into an art and a way of life. Be that as it may, Zeng is among those honored by Feng with the label "Champion's Poetry" (冠軍詩, 4/413-29), as is Mu Cao $(2 / 417-35)$.

As for prisoners, in addition to Liao Yiwu, Freebooters gives the floor to $\mathrm{Li}$ Bujia 李不嫁 (b. 1966) (10/301-21). Inmates appear in several of Li's poems. One of these is "On Entering Prison" (入獄記), a text at whose core lies a sense of dignity:

He pulls out my belt so my pants are loose / I quickly reach to hold them up / I can't let a prison guard going through the formalities / lay eyes on my shame / He has fished out my keys / but once I'm in I won't exactly be going out and locking up behind myself, right? // He kneels to take out my shoelaces / I tell him you can't kill a man with these and I won't kill myself / He lets on a gloomy smile / and proceeds to take off my glasses: / my eyes transform and the piercing cold that shoots out makes him shiver

\section{Disorientation}

I have said that there is something disorienting about Freebooters, and specifically that Feng's editorial footprint occasionally feels like it is all over the place but also triggers the intuition that it captures something essential about the Chinese poetry scene. By "all over the place" I mean that when browsing through Freebooters, I find myself bouncing back and forth between awestruck and baffled-and-exasperated. Awe-struck: by its energy, its inventiveness, its humor, its radicalism, its credible anti-elitism, its support of lesser-known voices and advocacy for vulnerable groups, its compelling conveyance of the poetry experience in today's China. Baffled and exasperated: by its extreme partisanship, its wildly fluctuating level of coherence within individual issues, the random element that appears to be part of its inventiveness, its looseness and incompleteness in regard to "normal" editorial technique. To both lists might be added the overwhelming size of the enterprise, meaning the sheer amount of text Freebooters has produced.

What I call looseness and incompleteness in regard to "normal" editorial technique refers, for instance, to the fact that Feng uses various terms associated with unofficial poetry as if they are interchangeable一民間 "unofficial," 地下 “underground,”體制外 “outside the system," 獨立 “independent,” 先鋒 
“avant-garde," 自由 “free"27_ just like he moves around names and titles from imperial China as section headings without any perceptible logic (again: to this reader, because maybe I just don't get it; and yes, the terms listed just now do overlap; and no, my observations are not intended as value judgments). It also refers to the frequent absence of composition dates for individual texts, of background information on individual authors, and of photo captions, all three types of information that are commonly included in publications such as this. Then again, this could point to editorial interventions (rather than negligence), motivated by the journal's radicalism and a concomitant desire to minimize the traceability of its contributors in the real world .... But that is too cloak-and-daggery and it hardly squares with their exuberant online presence in the Freebooters WeChat group and other places, or with the journal's attempts to reach outside readers through online announcements. Nor is the absence of composition dates, author bios, and photo captions consistent throughout the journal (I realize that as above, this observation may come across as the sorry grumblings of a hidebound academic).

In all, I feel that various tensions I perceive in Feng's project help explain the disorienting effect the journal has on me. Tension, for example, between Feng's drive as a system-builder - visible in his habit of "surveying" unofficial poetry from various angles, often including a historical perspective - and a style of operations that may be summed up as going it alone. When he re-entered the poetry scene in 2008 this was as one of several editors of a new journal called Underground (地下), but after the first few issues he struck out on his own to start Freebooters. (His affiliation with Underground has recently been revived and he is involved in other projects, but Freebooters very much appears to be his top priority.) Tension between narcissistic, playful, fun-loving aspects of the cult of poetry and Freebooters' dead-serious cultural-political positioning and emancipatory work, even if I know to invoke the scope of poethood to explain this. The promotion of Mu Cao's poetry and thereby of the notion of "comrade" poetry serves as an example: Feng has given Mu Cao much exposure, in Freebooters but also in an unofficially published, extensive collection of his poetry called Blue Sex (藍色的性) to mark his receipt of the aforesaid "underground" poetry prize in $2015 .{ }^{28}$ Tension between Freebooters' emancipato-

27 For example, Freebooters no. 18 is called China's Independent Poetry Journals and Underground Avant-Garde Poetry Movements (中國獨立詩刊暨地下先鋒詩歌運動卷), lumping together three of these six terms; and on the cover of the above-mentioned photograph companion, Historical Photo Companion to China's Independent Poetry Journals and Avant-Garde Poetry Movements (中國獨立詩刊暨先鋒詩歌運動歷史影像側), Underground has gone missing.

28 Mu Cao 墓草, Lanse de xing 藍色的性 (Blue Sex), unofficial, 2015. 
ry impulse, including regular attention to women's poetry (女性詩歌), and its simultaneous exudation of the rude-boy machismo and misogyny that are part of the transgressive discourse. Tension between easy, clichéd visions of unofficial poetry as projects run on a shoestring (to which I am not immune) and Feng's status as an editor of independent means who can afford to indulge his interest in professional print material for thousands of pages on end.

\section{Between a Religion and an Industry}

This brings me to two final points. One: we might ask with some justification if Freebooters is (A) truly an interesting journal or (B) merely the product of an idiosyncratic mind that happens to have a lot of time and money at its disposal. After noting that this is a false dichotomy, my vote goes to $\mathrm{A}$, with a caveat: especially in light of the journal's ambition to shape and frame the discourse on contemporary Chinese poetry, it is crucial that it be read and intepreted in abundant context. Phrased in more positive terms, Freebooters is an outlier, but one that adds to our insight into journal culture and the bigger picture of which it is a part. Two: if I had to pinpoint what it is that Freebooters captures about the Chinese poetry scene, this might be the phenomenon of poetry as a social practice that sits between a religion and an industry. Comfortably so. 